Article

\title{
The Relationship Between Strategic Orientation Dimensions and Hotel Outsourcing and Its Impact on Organizational Performance. An Application in a Tourism Destination
}

\author{
Tomás F. Espino-Rodríguez * (1) and Juan Carlos Ramírez-Fierro \\ Department of Economics and Business, Universiy of Las Palmas de Gran Canaria, Las Palmas de Gran Canaria, \\ C.P. 35017, Spain; direccion@latiendita-catering.com \\ * Correspondence: tomasfrancisco.espino@ulpgc.es; Tel.: +34-928-458-648
}

Received: 25 April 2018; Accepted: 27 May 2018; Published: 28 May 2018

check for updates

\begin{abstract}
The study analyzes whether the strategic orientation of the firm, measured in six dimensions, influences the level of outsourcing. It also analyzes whether outsourcing has an impact on organizational performance from financial and non-financial perspectives. To do so, an important European tourist destination is analyzed. The findings suggest that the majority of the strategic dimensions influence the hotel's level of outsourcing. The defensiveness and proactive dimensions are positively related to the level of outsourcing, whereas the competitive analysis and competitive aggressiveness dimensions influence it negatively. In addition, the riskiness dimension has a positive influence, whereas the dimension related to futurity does not influence the level of outsourcing. A positive and significant relationship is found between outsourcing and financial performance, whereas for non-financial performance, the relationship is not significant.
\end{abstract}

Keywords: outsourcing; financial performance; non-financial performance; strategic orientation; hotels

\section{Introduction}

Hotels want to develop new products and services that satisfy their clients' needs in as little time as possible, and this is achieved through innovation. This situation increases the difficulty of performing all the activities in-house and requires external suppliers to provide hotel services $[1,2]$. In addition, the tourism demand has evolved; the consumer in the tourism setting has become more demanding. Hotel establishments compete with each other, and the competition has become especially intense between new and consolidated tourist destinations. Tourism areas compete to adapt to tourists' needs, trying to provide a high level of quality, which leads to the growth and development of their territory $[3,4]$. The dynamism and high competitiveness of the market currently require hotel management strategies that focus on both current success and investments in activities that promote a competitive advantage for future success. Therefore, hotels must redesign their strategies, redesign their processes, and outsource the activities that they are not capable of developing internally [5]. Outsourcing occurs when internal activities that could be and/or have previously been performed in-house are executed by independent suppliers [6].

Due to cost pressures and market competition in a dynamic and globalized setting, many businesses use outsourcing to improve sustainability and ensure their survival [7]. Hotels outsource a wide range of activities, such as laundry, cleaning, food and beverage, maintenance, and security [8,9], which makes it necessary to carry out more research in this area. 
Different types of research can be carried out in this area. Some studies analyze the factors that determine the degree of outsourcing. Various studies in the literature describe the variables that determine the use of outsourcing, but few consider the strategic orientation as a determinant factor in the use of outsourcing [10]. The present study considers the hotel's strategic orientation as a factor that can determine its outsourcing level. To do so, the six strategic dimensions from the study by Venkatraman [11] are used. These dimensions include factors related to a company's strategy that are still relevant today. Analyzing the relationship between the strategic orientation and outsourcing makes it possible to establish the influence of the strategic dimensions on the hotel's outsourcing level, an aspect that has hardly been investigated in the services outsourcing literature.

Other studies analyze the possible consequences or impact of outsourcing on the firm. One of the main consequences that must be analyzed is its impact on organizational results. Some studies have analyzed the influence of outsourcing on organizational performance in the hotel sector $[1,12,13]$, but no recent studies have examined this question. Lahiri [14] point out a lack of empirical studies about the possible influence of outsourcing on organizational performance.

It is important to find out whether this strategy, increasingly utilized by hotels, has an impact on the organizational result, given that the expectation is that almost $60 \%$ of workers will be outsourced in the year 2020 [15]. In the literature, it is not clear whether outsourcing has an influence on firm performance. The studies carried out in different sectors, to date, analyze whether the influence of outsourcing on organizational performance can be positive, negative, or have no impact, often depending on how outsourcing or performance is measured [14]. A number of advantages or benefits are attributed to outsourcing, such as cost reduction, greater flexibility, a focus on core competences, and access to specialized knowledge [16,17]. These benefits generate an added value for the firm, which can improve organizational performance. Thus, we intend to analyze whether outsourcing influences organizational performance in the hotel sector in the current context. Managers need to know the consequences of the outsourcing practices followed by other firms, in order to manage their own outsourcing with criteria of sustainability in terms of performance.

The objectives of the paper are the following:

(a) Analyze the impact of the strategic orientation dimensions on the hotel's outsourcing level.

(b) Study whether there is an influence of the outsourcing level on organizational performance.

\section{Literature Review}

\subsection{The Strategic View of Outsourcing Based on a Resource-Based View of the Firm}

Many authors consider that the decision to outsource has strategic importance [18-20]. As a strategic decision, outsourcing must be evaluated for its effects on the competitive advantage and harmony with the decisions that involve changes in the organization's environment [21]. Likewise, the decision to outsource must form part of the strategic management, which is a discipline responsible for studying how organizations formulate and implement strategies to reach desired objectives [22]. According to Hofer, Murray, Charan and Pitts [23], the field of strategic management is related to two large areas: the first area studies the strategic processes of organizations, such as setting objectives, formulating strategies, and designing administrative structures and systems; and the second area studies the different functions or responsibilities of top management, which include activities as diverse as the coordination and integration of the tasks in different functional areas, the participation in key operative and strategic decisions, negotiation with external collectives, and the representation of the organization. The resource-based view of the firm predicts that an organization with a rich competency base develops the activities in-house. However, firms less prepared to develop the activity internally can outsource it [24]. The resource-based perspective is often viewed as a key theory in the strategy literature to explain outsourcing $[19,25]$ because the decision to outsource is often considered a strategic decision that can complement or substitute the firm's resources and capabilities [26]. 
As Greaver [27] points out, strategic outsourcing considers that the "make and buy" decisions are high level, presenting fundamental questions of the firm, such as the vision of the future, the basic competencies, the structure, the costs, and the competitive advantage. The resource-based view of the firm considers that the firm's resources and capabilities allow it to achieve a sustained competitive advantage [28]. For the outsourcing decision to make sense, it should permit the firm to develop a capability that leads to sustained superior performance. According to McIvor [25], firms can obtain complementary capabilities thanks to suppliers when they do not have the necessary resources to invest in developing an activity or process. Firms can expand their own knowledge and physical investment capabilities by exploiting the facilities and program investments of outside sources [24]. Therefore, the resource-based view of the firm considers that the resources can be exploited through contracts. From the perspective of resources and capabilities, we can define outsourcing as a strategic decision that involves the external contracting of certain activities that do not contribute to the formation of core activities, although they may be essential to their formation, that are necessary for manufacturing goods or providing services, through the establishment of agreements or contracts with firms with greater capability of carrying out these activities, in order to improve the competitive advantage [29]. The definition indicates that outsourcing has to form part of the firm's strategy and pursue the search for and maintenance of the competitive advantage. Both aspects are considered in this study.

The decision to outsource should be included in the firm's strategy, reviewing the processes and measuring their consequences in both strategic and financial terms. This study first analyzes to what degree outsourcing is included in the firm's strategy. To do so, we analyze the different dimensions of strategic orientation according to Venkatraman [11]. Second, the study analyzes the consequences for the competitive advantage measured through the organizational result.

\subsection{The Hotel's Strategic Orientation and Its Influence on the Level of Outsourcing.}

Highly competitive environments produce changes in organizations and obligate their managers to look for strategies that allow them to maintain their competitive advantage [30]. The strategic orientation consists of a set of behaviors to carry out the company strategy [31]. Like culture, the strategic orientation is considered a critical factor that can determine a company's success or failure. This factor particularly affects managers because it is viewed as a controllable variable that can be acted on to improve business performance. Various studies show that paying special attention to the strategic orientation can lead to better performance in emerging economies [32]. The strategic orientation focuses on the way companies must interact with the environment, clients, competitors, and technology to reach their business objectives [33,34]. The efficiency of a company's strategy depends on the fit between the strategic options and the dynamism of the market [35]. Venkatraman [11] conceptualized six key dimensions of the strategic orientation:

-Aggressiveness dimension: This dimension reflects the way the company assigns its resources to improve its market position at a rhythm that is somewhat faster than its competitors. The objective is to have a greater market share than competitors [36], which can occur through a cost leadership strategy [37-39], explosion and expansion (e.g., improving the short-term competitive position) [40], innovation [41], or differentiation and pricing [42].

-Competitive analysis dimension: This dimension reflects the capacity to perform an in-depth analysis of the main reasons for problems and design the best alternative solution. It is related to the degree of internal consistency in assigning resources to reach the company's objectives.

-Defensiveness dimension: This dimension is related to the defensive behavior described by Miles and Snow [43], and it is expressed in terms of the emphasis on seeking cost-reduction methods and operational efficiency. It is also related to defending the company's main technology [44] and the concept of defensive actions from Miles and Cameron [45] (e.g., preserve its own products, markets, and technologies).

Futurity dimension: This dimension represents the degree to which decisions are strongly influenced by future events. It reflects topics such as sales objectives, changes in clients' tastes, 
or environmental changes, and it is expressed as the company's adoption of a more strategic view [46].

- Proactiveness dimension: This dimension reflects the constant search for new market opportunities that may or may not be related to the company's current operations [36]. Innovations in products and processes are carried out with this orientation [47]. Proactiveness explains the company's effort to reach the first position in the market [38], trying to surpass its competitors. A tendency toward this strategic orientation also means that the maturity or life cycle of a product is managed [36].

- $\quad$ Riskiness dimension: This dimension measures the company's degree of risk, which reflects its criterion for choosing its resource assignment strategy and its general decision-making model.

The present study aims to analyze the relationship between a hotel's strategic orientation and its level of outsourcing. Some studies in the literature analyze the relationship between the competitive strategy and outsourcing $[20,48]$, although the influence of other types of strategies is still unclear. In the public sector, González, Gascó and LLopis [10] analyze the relationship between outsourcing in Spanish town halls and the different dimensions of the Miles and Snow strategy. These authors show that town halls that follow a defensive strategy have a lower level of outsourcing than those using a prospective or reactive strategy. Studies carried out in the hotel sector indicate that the type of competitive strategy influences the hotel's level of outsourcing [20]. Espino-Rodríguez and Chun-Lai [20] show that the outsourcing of an activity can depend on the type of competitive strategy followed. Although the strategic orientation typology employed in this study is different, it is reasonable to infer that the different strategic orientations the hotel follows can condition the level of outsourcing. No previous studies have analyzed the six dimensions described above and the level of outsourcing. However, depending on the hotel's emphasis on each of Venkatraman's [11] strategic dimensions, the level of outsourcing can be greater or less, as other strategy classifications show that the strategy can have an impact on outsourcing. For this reason, we propose the following hypothesis:

Hypothesis 1. The strategic orientation of the hotel (competitive analysis, aggressiveness, defensiveness, futurity, proactiveness, riskiness) influences the level of outsourcing.

This hypothesis is divided into 6 sub-hypotheses, one for each strategic dimension.

Hypothesis 1a. Competitive analysis in hotels' strategic orientation is related to the level of outsourcing.

Hypothesis 1b. Aggressiveness in hotels' strategic orientation is related to the level of outsourcing.

Hypothesis 1c. Defensiveness in hotels' strategic orientation is related to the level of outsourcing.

Hypothesis 1d. Futurity in hotels' strategic orientation is related to the level of outsourcing.

Hypothesis 1e. Proactiveness in hotels' strategic orientation is related to the level of outsourcing.

Hypothesis 1f. Riskiness in hotels' strategic orientation is related to the level of outsourcing.

\subsection{Outsourcing and Organizational Performance}

Cost reduction is one of the recognized benefits of outsourcing. Organizations value outsourcing if the operational costs can be reduced and these savings can be reinvested in more competitive processes [49]. This reduction in costs has its origin in taking advantage of economies of scale due to the fact that the outsourcing vendor serves many clients, making the unitary cost of the service lower [50]. Therefore, outsourcing often improves cost competitiveness because the firm can eliminate tasks that are not productive and reinforce other activities that are not outsourced [51]. An outsourcing 
strategy allows a greater organizational result and increases productivity [52]. The reduction in investments is another recognized advantage of outsourcing that can have an impact on improving financial performance. Other advantages, apart from economic benefits such as cost reduction, are recognized in outsourcing and can also give greater added value to firms. Thus, outsourcing is an important tool for firms because it allows them to obtain flexibility, speed, and other requirements in a highly competitive environment [53]. Outsourcing makes it possible to access better resources and capabilities that can become positional advantages, leading to an improvement in organizational performance [54]. An organization must focus on the activities that are core competences and outsource the activities that do not form part of the basic core or for which they lack the necessary resources and capabilities [9]. The decision to outsource allows the firm to free up necessary resources to focus on the core competences and develop new opportunities [55]. Therefore, companies that choose to outsource are seeking greater value and other outcomes such as quality improvement, investment and risk reduction, and increases in flexibility, scalability, and innovation, thus ensuring long-term relationships [17]. These aspects must be translated into an improvement in organizational performance from both financial and non-financial perspectives. Outsourcing allows access to specialized companies that add quality to the product or service, and it reduces the size of firms and their bureaucratic costs [16].

Outsourcing can be used to address deficiencies in the results of the activity and the organizational results [56], which means that when a firm outsources a certain function, it can increase its own performance [13]. Through outsourcing to outside specialist organizations, firms can achieve a higher level of employee performance and productivity [57]. This leads to a higher level of employee compensation and satisfaction, resulting in greater client satisfaction. The outsourcing decision can be explained as choosing between internal or external resources to fulfill an activity, in order to obtain a competitive advantage [51]. As all of these benefits accumulate in the form of reduced costs, reduced uncertainty, protection of core competences, and greater efficiency, thanks to outsourcing, firms will experience a positive impact on the organizational performance [58]. Surku Cetinkaya [54] shows that there is a relationship between the success of outsourcing and organizational performance on intangible measures related to the information technology activity in the hotel sector.

Bolat and Yilmaz [13] show that the organizational performance is greater after outsourcing than before it in the hotel sector. In addition, Espino Rodríguez and Padrón Robaina [12] demonstrate that hotel outsourcing positively influences financial performance and the hotel activity index, measured through the room occupation rate, extra income, and the number of new products and services. In other sectors, some studies also show the influence of outsourcing on organizational performance [58-60]. The effects of outsourcing on firm performance are analyzed in this study from a dual financial and non-financial perspective. The following hypotheses are proposed:

Hypothesis 2. Outsourcing has a positive effect on financial performance in the hotel sector.

Hypothesis 3. Outsourcing has a positive effect on non-financial performance in the hotel sector.

The previous hypotheses make it possible to analyze the influence of the strategic orientation (measured through the dimensions analyzed above) on the level of outsourcing, and how this level of outsourcing influences the organizational result, considered from the dual perspective of financial and non-financial performance.

\section{Methodology}

\subsection{Study Setting and Sample}

The geographical area where the study was carried out is the Canary Islands, which form part of one of the main European tourist destinations. In the year 2017, more than 14 million tourists arrived to the Canary Islands, which signified a 7.6\% increase compared to the previous year [61]. Within Spain, 
the Canary Islands is one of its main tourist destinations. The Canaries constitute one of the tourism motors in Spain, surpassing the Balearic Islands and Catalonia in the national ranking. Canaries is where the spending by foreign tourists is greater, compared to other tourist areas in Spain [61]. It has a pleasant subtropical climate and is visited by many tourists from Germany, the Netherlands, the United Kingdom, and Ireland.

Within the Canary Islands, Gran Canaria was chosen to carry out the field work. In 2017, Gran Canaria received more than 4.5 million tourists [62], which consolidated it as one of the most relevant tourism clusters in the Sun and Beach destination. To carry out the field work, the number of 3-to-5 star, sun and beach hotel establishments was identified. By consulting various databases (Tourism Information System TURIDATA of the Tourism Council of the Government of Canarias and the Tourist Board of Gran Canaria), a list was made with the data for these hotels, obtaining 71 hotels. To obtain the study data, the hotels were approached through a personal survey filled out by the managers. The hotel managers were contacted first by email and telephone and asked to participate in the study. Later, an appointment was made to go to the hotel and administer the survey.

Of the 71 hotels, 63 hotels participated in the study, with 77 personal surveys filled out by their managers and assistant managers. Some hotels only had the figure of the manager, and so we obtained one survey because many hotels do not have assistant managers. Currently, in the hotel sector, whether due to operative efficiency or the economic crisis experienced in recent years, there is a tendency to have fewer managers. In addition, in one case a manager ran three hotels from the same chain and did not have an assistant manager, and some worked in a hotel chain that had eliminated the figure of the assistant manager in establishments with less than 400 rooms. In some cases, managers were also responsible for two hotels at the same time. In spite of all this, a real response rate of $88.73 \%$ was obtained. This percentage includes the majority of the tourist hotels on Gran Canaria, and so sample representativity is fairly high.

\subsection{Measures of the Variables}

To elaborate the questionnaire, the theoretical literature was reviewed on how to measure the strategic orientation of the hotel, the level of outsourcing, and organizational performance. Before the data collection, the questionnaire was pre-tested for content validity [63]. Information was obtained through the pre-test carried out by hospitality and tourism researchers and practitioners on the accuracy, clarity, and readability of the survey items. The content validity of the survey instrument was established through the adoption of validation instruments by other researchers in the literature on strategy and outsourcing. The questionnaire was pre-tested by two researchers who carry out studies in hospitality and tourism management and two relevant practitioners (hotel managers) in the tourism sector in Canaries. As a result, the survey was corrected and refined, and some items were re-written.

Degree of hotel outsourcing perceived by the manager. There are different ways to measure an organization's degree of outsourcing. Some studies use their production process activities to measure the degree of outsourcing [20]. However, given the objectives of the proposed research model, we wanted to determine the managers' perception of the existing level of outsourcing in the hotel, that is, whether they perceive that their hotel outsources a lot or a little, the departments' degree of dependence on external companies, the percentage of external workers, etc. Thus, the managers interviewed expressed their degree of agreement or disagreement with 5 statements designed to measure the degree of perceived outsourcing in their hotels, using a Likert-type numerical scale from 1 to 7 (see Appendix A).

The hotel's strategic orientation. This construct is composed of questions that measure the strategic orientation of the hotel based on the scale by Venkatraman [11]. This scale was adapted to the hotel sector by Han [31] and used as a reference in this study. To do so, 24 indicators were distributed in 6 key dimensions (competitive analysis, aggressiveness, defensiveness, futurity, proactiveness, and riskiness) to measure the strategic orientation. Interviewees rated these indicators on a Likert-type scale from 1 to 
7, where 1 indicates that the managers give little support, and 7 indicates that they strongly recognize and support aspects of the strategic orientation (see Appendix A).

Organizational performance. This study aims to test the relationship between the level of outsourcing and organizational performance. Thus, each manager was asked to evaluate the financial and non-financial performance because they both form part of organizational efficiency [64]. Financial performance indicators, such as return on sales and return on profit margins were measured. In addition, other measures not related to financial aspects were used, namely those related to stakeholder (customers, employees, suppliers) satisfaction [65-67]. The questions related to the organizational result were based on a Likert-type numerical scale from 1 to 7 points, asking to what degree the expectations were met on 13 relevant hotel indicators. These scales have been validated in the hotel sector by other studies [66-68].

Common method bias was examined through statistical methods [69]. Harman's one-factor test for common method bias using exploratory factor analysis with SPSS 18.00 indicates a factor that explains only $14.19 \%$ of the variance. This factor is clearly below the cut-off threshold of $50 \%$. This shows that common method bias was not a significant issue in our study. In addition, common method bias is generally less of a concern when the targets are top managers because they are the main respondents who have the key information $[70,71]$.

\section{Analysis and Results}

Partial Least Squares (PLS), specifically SmartPLS [72], was used to test the study hypotheses in a way that maximizes the explained variance [73]. PLS is less demanding with regard to the minimum requirements for the sample size and the distribution of variables, compared to co-variance techniques based on structural equation models such as LISREL [74]. PLS does not require that the data stem from normal or known distributions [75]. PLS is used where the theory is not solidly developed, which is the case of the relationship between the dimensions of the strategic orientation and the level of outsourcing, or when the sample is not very large. In a systematic and comprehensive analysis, PLS examines: (1) the assessment of the measurement models by analyzing the relationships between the latent variables and their indicators; and (2) the assessment of the structural model, examining the relationships between latent variables or constructs [76].

\subsection{Measurement Model}

First, we carried out an evaluation of each item's individual reliability, convergent validity, and discriminant validity coefficients [77]. Using the criterion followed previously, we used the items that had a factor loading greater than $0.5[75,78]$. The items that did not reach this threshold were eliminated. With regard to the composite reliability (CR), Table 1 shows that all the constructs are reliable, exceeding the reference value of 0.7 , and reaching composite reliability $(\mathrm{CR})$ values between 0.842 and 0.907 . In addition, the Cronbach's alpha for each of the constructs exceeded the recommended value of 0.7 , reaching values between 0.818 and 0.907 [79]. The average variance extracted (AVE) of all the constructs exceeds the required threshold of 0.5 , with values between 0.529 and 0.728 , showing that more than $50 \%$ of the construct's variance is due to its indicators. Therefore, the results present convergent validity.

Table 2 reveals that the square root of the AVE (main diagonal) is superior to the correlations between the constructs in all cases, guaranteeing discriminant validity. The table also shows that the correlations take lower values than their respective reliabilities $(0.831-0.910)$. Therefore, all the constructs support the discriminant validity of the scales used to measure the model. To ensure the absence of multicollinearity, this study conducts a variance inflation analysis (VIF). None of the independent variables related to the strategic orientation in the model exceeds a variance inflation factor of 2.945. The VIF range between 1.292 and 2.954. Thus, the values do not exceed the critical threshold of 3.33. VIF of less than 3.3 shows an excellent value [80]. 
Table 1. Evaluation of the measurement model.

\begin{tabular}{|c|c|c|c|c|c|}
\hline Factors & $\begin{array}{l}\text { Factor } \\
\text { Loadings }\end{array}$ & $\mathbf{t}$ & $\begin{array}{l}\text { Composite } \\
\text { Reliability }\end{array}$ & $\begin{array}{c}\text { Variance } \\
\text { Extracted AVE }\end{array}$ & Alpha \\
\hline \multicolumn{6}{|c|}{ Competitive Analysis dimension } \\
\hline $\mathrm{C} 1$ & 0.732 & 4.679 & 0.889 & 0.574 & 0.863 \\
\hline $\mathrm{C} 2$ & 0.803 & 5.385 & & & \\
\hline C3 & 0.782 & 4.422 & & & \\
\hline $\mathrm{C} 4$ & 0.787 & 3.852 & & & \\
\hline C5 & 0.734 & 3.297 & & & \\
\hline C6 & 0.703 & 3.003 & & & \\
\hline \multicolumn{6}{|l|}{ Aggressiveness dimension } \\
\hline $\mathrm{A} 1$ & 0.884 & 2.851 & 0.857 & 0.670 & 0.818 \\
\hline A2 & 0.894 & 2.861 & & & \\
\hline A3 & 0.654 & 2.136 & & & \\
\hline \multicolumn{6}{|l|}{ Defensiveness dimension } \\
\hline D1 & 0.694 & 2.764 & 0.880 & 0.652 & 0.873 \\
\hline D2 & 0.704 & 2.481 & & & \\
\hline D3 & 0.886 & 3.188 & & & \\
\hline D4 & 0.919 & 3.237 & & & \\
\hline \multicolumn{6}{|l|}{ Futurity dimension } \\
\hline F1 & 0.564 & 1.974 & 0.842 & 0.529 & 0.906 \\
\hline $\mathrm{F} 2$ & 0.643 & 2.333 & & & \\
\hline F3 & 0.791 & 2.923 & & & \\
\hline $\mathrm{F} 4$ & 0.984 & 2.887 & & & \\
\hline F5 & 0.567 & 1.823 & & & \\
\hline \multicolumn{6}{|l|}{ Proactiveness dimension } \\
\hline $\mathrm{P} 1$ & 0.695 & 2.708 & 0.878 & 0.709 & 0.829 \\
\hline P2 & 0.985 & 3.813 & & & \\
\hline P3 & 0.821 & 3.293 & & & \\
\hline Riskiness dimension & & & 0.891 & 0.675 & 0.845 \\
\hline $\mathrm{R} 1$ & 0.737 & 4.811 & & & \\
\hline R2 & 0.745 & 5.077 & & & \\
\hline R3 & 0.877 & 7.059 & & & \\
\hline R4 & 0.912 & 9.846 & & & \\
\hline Level of outsourcing & & & 0.907 & 0.665 & 0.872 \\
\hline N1 & 0.832 & 11.96 & & & \\
\hline N2 & 0.688 & 8.337 & & & \\
\hline N3 & 0.741 & 10.31 & & & \\
\hline N4 & 0.909 & 17.15 & & & \\
\hline N5 & 0.886 & 16.19 & & & \\
\hline Financial performance & & & 0.907 & 0.665 & 0.872 \\
\hline FP1 & 0.880 & 3.803 & & & \\
\hline FP2 & 0.882 & 3.731 & & & \\
\hline FP3 & 0.907 & 3.901 & & & \\
\hline FP4 & 0.674 & 2.948 & & & \\
\hline FP5 & 0.704 & 3.985 & & & \\
\hline Non-financial performance & & & 0.930 & 0.728 & 0.907 \\
\hline NFP1 & 0.907 & 4.352 & & & \\
\hline NFP2 & 0.908 & 4.298 & & & \\
\hline NFP3 & 0.753 & 3.215 & & & \\
\hline NFP4 & 0.816 & 3.879 & & & \\
\hline NFP5 & 0.869 & 4.483 & & & \\
\hline
\end{tabular}


Table 2. Square root of the average variance extracted (AVE) and correlations matrix.

\begin{tabular}{lccccccccc}
\hline \multicolumn{1}{c}{ Variables } & $\mathbf{1}$ & $\mathbf{2}$ & $\mathbf{3}$ & $\mathbf{4}$ & $\mathbf{5}$ & $\mathbf{6}$ & $\mathbf{7}$ & $\mathbf{8}$ & $\mathbf{9}$ \\
\hline 1. Competitive analysis & $\mathbf{( 0 . 7 5 9 )}$ & & & & & & & & \\
2. Aggressiveness & -0.014 & $\mathbf{( 0 . 8 1 9 )}$ & & & & & & \\
3. Defensiveness & 0.602 & 0.081 & $\mathbf{( 0 . 8 0 7 )}$ & & & & & \\
4. Futurity & 0.359 & 0.059 & 0.471 & $\mathbf{( 0 . 7 2 7 )}$ & & & & \\
5. Proactiveness & 0.410 & -0.049 & 0.390 & 0.623 & $\mathbf{( 0 . 8 4 2 )}$ & & & \\
6. Riskiness & 0.201 & 0.342 & 0.269 & 0.167 & 0.020 & $\mathbf{( 0 . 8 2 1 )}$ & & \\
7. Level of outsourcing & -0.313 & -0.147 & 0.121 & 0.188 & 0.204 & 0.292 & $\mathbf{( 0 . 8 1 6 )}$ & \\
$\begin{array}{l}\text { 8. Financial } \\
\text { performance }\end{array}$ & 0.273 & -0.223 & 0.250 & 0.229 & 0.318 & 0.102 & 0.216 & $\mathbf{( 0 . 8 1 5 )}$ \\
9. Non-financial & 0.218 & 0.070 & 0.262 & 0.176 & 0.153 & 0.143 & 0.191 & 0.673 & $\mathbf{( 0 . 8 5 3 )}$ \\
performance & & & & & & & & & \\
\hline
\end{tabular}

Note. The elements on the diagonal (values between parentheses represent the square root of the variance extracted (AVE), and the values outside the diagonal represent the correlations between the constructs.

\subsection{Structural Model}

Table 3 and Figure 1 show the structural model resulting from the PLS analysis. The assessment of the fulfillment of the hypotheses was carried out through the variance explained $\left(R^{2}\right)$ in the dependent variables and the path coefficients $(\beta)$ for the model. In order to verify the significance of the $\beta$ values and produce standard errors and $t$-values, the bootstrapping (5000 resamples) technique was applied. The estimated $\mathrm{R}^{2}$ values for level of outsourcing and financial and non-financial performance, respectively, are $0.546,0.048$, and 0.037 . The majority of the strategic dimensions influence the hotel's level of outsourcing. For example, it is negatively influenced by the competitive analysis $(\beta=-0.764$, $p<0.001)$ and competitive aggressiveness $(\beta=-0.327, p<0.01)$ dimensions. This suggests that Hypotheses $1 \mathrm{a}$ and $1 \mathrm{~b}$ are accepted. In addition, the results suggest that the defensiveness $(\beta=0.336$, $p<0.05)$ and proactiveness $(\beta=0.339, p<0.05)$ dimensions positively influence the level of outsourcing perceived by the manager. Therefore, Hypotheses $1 \mathrm{c}$ and $1 \mathrm{e}$ are also accepted. The dimension related to futurity is not significantly associated with the perceived level of outsourcing ( $\beta=0.037, p<0.317$ ). This indicates that Hypothesis $1 \mathrm{~d}$ is rejected. In the case of the riskiness dimension $(\beta=0.454$, $p<0.001$ ), it positively influences the level of outsourcing, which indicates that the more conservative the hotel, the higher the level of outsourcing. Thus, Hypothesis $1 \mathrm{f}$ is accepted. The items that measure riskiness are in the opposite direction from risk; that is, a higher score on the items means that a hotel follows a more conservative strategic orientation (see Appendix A). These results together support hypothesis 1.

The level of outsourcing influences the financial performance, with the relationship being positive and significant $(\beta=0.217, p<0.05)$. This result suggests support for hypothesis 2 . By contrast, the relationship between the level of outsourcing and non-financial performance is positive, but not significant at a level of $5 \%$. In addition, the $\beta<0.20$. Some authors establish that a level below 0.2 is not acceptable [77], and so hypothesis 3 is not supported. 
Table 3. Results of the structural model.

\begin{tabular}{|c|c|c|c|}
\hline \multirow{2}{*}{ Hypothesis } & \multicolumn{3}{|c|}{ Structural Model } \\
\hline & $\begin{array}{l}\text { Standardized } \\
\text { Coefficients }\end{array}$ & t-Value & $\mathbf{R}^{2}$ \\
\hline $\begin{array}{l}\text { Area of competitive analysis } \rightarrow \text { level of } \\
\text { outsourcing }\end{array}$ & $-0.764^{* * *}$ & 4.985 & \\
\hline Aggressiveness $\rightarrow$ level of outsourcing & $-0.327^{*}$ & 2.245 & \\
\hline Defensiveness $\rightarrow$ level of outsourcing & $0.336^{*}$ & 1.845 & $54.06 \%$ \\
\hline Futurity $\rightarrow$ level of outsourcing & 0.037 & 0.317 & \\
\hline Proactiveness $\rightarrow$ level of outsourcing & $0.339 *$ & 1.730 & \\
\hline Riskiness dimension $\rightarrow$ level of outsourcing & $0.454^{* * *}$ & 4.127 & \\
\hline $\begin{array}{l}\text { Level of outsourcing } \rightarrow \text { Financial } \\
\text { performance }\end{array}$ & 0.217 * & $1.672 *$ & $4.68 \%$ \\
\hline $\begin{array}{l}\text { Level of outsourcing } \rightarrow \text { Non-financial } \\
\text { performance }\end{array}$ & 0.192 & 1.592 & $3.68 \%$ \\
\hline GoF (Goodness-of-fit criterion) & \multicolumn{3}{|c|}{0.367} \\
\hline
\end{tabular}

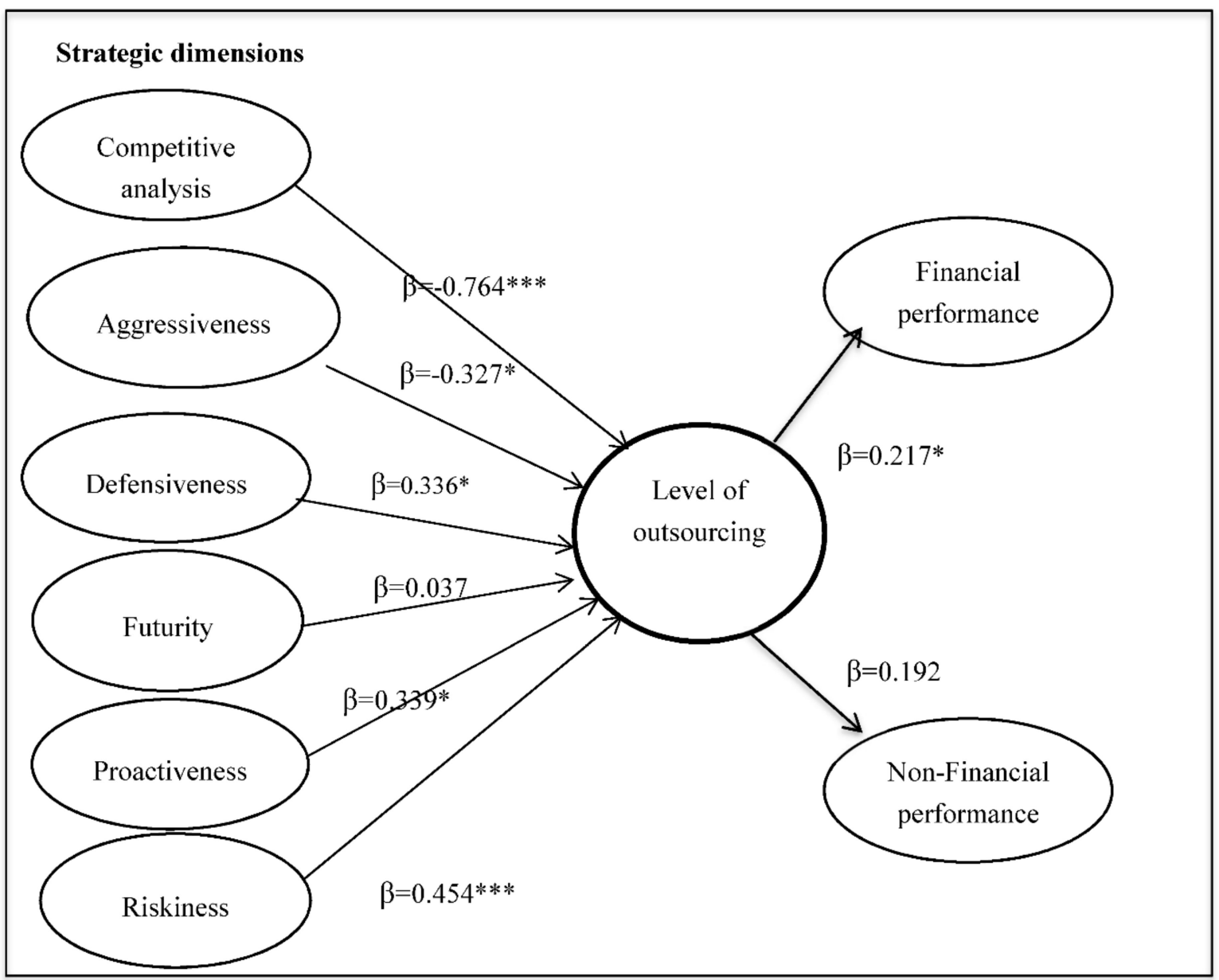

Figure 1. Structural model. ${ }^{* *} p<0.001,{ }^{* *} p<0.01,{ }^{*} p<0.05$.

Finally, we test the goodness of fit of the model. The PLS technique does not have an index that can provide a validation of the model. Thus, authors like Tenenhaus, Vinci, Chatelin and Lauro [81] propose an overall criterion for its validation. Specifically, the Goodness-of-fit (GoF) indicator was applied, which consists of the geometric mean of the average of the communalities by the mean of $\mathrm{R}^{2}$. 
A GoF that exceeds 0.36 indicates a model with good fit [77]. In the present study, the value is 0.367 (see Table 3), and so the model has sufficient predictive quality.

$$
\mathrm{GoF}=\sqrt{\overline{\text { Communality }} \times \bar{R}^{2}}
$$

\section{Discussion}

The results show that all the dimensions, except futurity, influence the hotel's level of outsourcing. Thus, the dimensions that influence it negatively are: (i) competitive analysis and (ii) competitive aggressiveness. The dimensions that positively influence the level of current outsourcing perceived by the manager are: (i) defensiveness, (ii) proactiveness, and (iii) riskiness. The dimension related to futurity is not significantly associated with the perceived level of outsourcing, which reinforces our proposal that the hotel's strategic vision has become a more tactical vision where financial results are given priority. In this regard, the view of the future competitive advantage and the analysis of future predictions do not coincide with either high or low levels of outsourcing.

Moreover, the fact that the defensiveness and proactiveness dimensions positively influence the level of outsourcing is coherent with the results obtained in the first study objective. Hotels are emphasizing methods for cost reduction, operative efficiency, and service quality, in addition to working proactively in the search for new market opportunities that can provide better results, which can be related to a higher level of outsourcing. Regarding the Riskiness dimension, the findings suggest that the hotel's reduced willingness to take risks influences the way of assigning resources to reach these objectives and the decision-making processes related to outsourcing. The more conservative the strategic orientation of the hotel is, the greater its level of outsourcing. This result suggests that hotels do not take risks by investing in operations to develop in-house because they do not have the core competences or resources and capabilities to carry them out. Instead, they opt to outsource these activities to specialized suppliers [25]. Investing in activities that do not form part of the core competences, rather than outsourcing them, could be quite risky for the hotel.

The competitive analysis and competitive aggressiveness dimensions negatively influence the hotel's level of outsourcing. The more planning and coordination there is among the different functional areas, the lower the degree of outsourcing. These findings are coherent with Quinn and Hilmer [18], who state that outsourcing can produce a loss of cross-functional skills. Interaction among employees from different departments can provide solutions and ideas, and functional integration has to do with the information shared among functions, cooperation, and group work [82]. Therefore, excessive dependence on the supplier can impede knowledge creation, which can lead to new services and processes. Hotels that follow this strategic orientation see a solution to their problems in performing activities in-house rather than outsourcing. These hotels more closely analyze the reasons for their problems and design alternative solutions, and, therefore, they present a lower degree of outsourcing. They consider that outsourcing is not going to solve their internal problems, and they prefer to design alternatives that allow them to develop their capabilities internally.

Furthermore, the more aggressive the hotel is, in terms of improving its position in the market through a competitive strategy involving price reduction, the lower its degree of outsourcing. Espino-Rodríguez and Chun-Lai [20] do not find a positive relationship between the cost leadership strategy, which involves offering lower prices, and the degree of current outsourcing of the activity. This result leads to the need to discover how hotels lower prices, as there are many ways to do this in an attempt to gain market share. Although the findings suggest that outsourcing is used to reduce costs, it is not being used to lower prices, probably because these hotels are dedicated to tourists who demand high quality and service.

The findings show that there is a positive influence between the level of outsourcing and financial performance, indicating that hotels that outsource the most have a better financial result. In other words, they present greater profitability, a higher occupancy rate, and greater profit margins or return assets. This result indicates that one of the main benefits that hotels are obtaining with outsourcing 
is the reduction in operative costs, as well as an improvement in the efficiency of the operations [83]. The positive influence on the financial performance or questions related to productivity and profitability is also shown in the studies by Espino Rodríguez and Padrón Robaina [12] and Bolat and Yilmaz [13]. Mohiuddin and $\mathrm{Su}$ [24] also find a positive relationship between outsourcing of non-core activities and integrated firm-level performance. Mudambi and Venzin [84] indicate that outsourcing is not static, and that the aim of the firm is to create value for the stakeholders.

However, the findings do not support a strong relationship between the level of outsourcing and non-financial performance. Outsourcing does not manage to improve or harm non-financial aspects such as the level of satisfaction of employees, clients, and suppliers. This result coincides with those from the study by Chatzoglou and Saragiannidis [1] demonstrating that outsourcing has no effect on non-financial performance. From an academic point of view, the study shows a theoretical relationship between strategic orientation, outsourcing, and organizational performance. Different strategic dimensions were analyzed for this purpose. Moreover, the study shows that the scales obtained for the different measures are reliable and, therefore, can be used in other studies. It also reveals that the strategic orientation is related to the use of external suppliers, which indicates that the company strategy can be a determinant in establishing a hotel's degree of outsourcing. The positive influence on the organizational result indicates that outsourcing can influence the competitive advantage. It would be a strategy for managers to consider in the future because it allows hotels to improve their financial performance and, therefore, their profitability. However, it is important to take into account the consequences of outsourcing for other aspects related to quality and client service. Regarding the implications for practitioners, this study produces knowledge and helps managers with decisions about outsourcing based on the different strategic dimensions. Depending on the intensity of a certain strategic dimension, hotels will be able to use more or less outsourcing. Managers must analyze the advantages of outsourcing, that is, whether the adoption of outsourcing is beneficial for the hotel, and whether it compensates from a financial and non-financial point of view. To do so, hotels should choose those activities that do not influence the competitive advantage, and that help to fulfill the strategic targets. The phases of the implementation of the outsourcing should be the keys to improving performance. Moreover, hotels should have measuring and evaluation systems that determine whether outsourcing will make it possible to improve the hotel's performance. Outsourcing is a dynamic strategy, and so managers should be constantly analyzing the evolution of the outsourcing in different aspects related to organizational performance. Furthermore, given the importance of the Canary Islands in the tourism sector, these results could be taken into account by other tourism areas. To improve the benefits of outsourcing, hotels and suppliers should foment a culture of inter-organizational relationships that make it possible to take advantage of profits.

Our study presents some limitations that can lead to future research. One limitation stems from the fact that the study was carried out in only one tourist destination. Thus, future research should consider other tourist destinations in order to compare the results obtained here. This line of research can also be applicable to other sectors (logistics, marketing, healthcare, banking, etc.). Future studies should consider the relationship between the strategic orientation and outsourcing, considering other classifications of the strategic orientation found in the literature. It is also important to be cautious in interpreting the results, and future studies should incorporate real measures of the financial result, rather than subjective measures. In addition, other measures related to financial performance, other than those employed in this study, should be considered in the future. This study measured the organizational performance through the managers' perception, and so it would be relevant to include other individuals from the hotel, such as employees or clients. In this regard, it would be interesting to find out the impact of outsourcing on employees' satisfaction by asking them, or to survey clients about quality when deciding to outsource. For example, in the future, it would be desirable to analyze how outsourcing influences the online reputation perceived by the clients.

Author Contributions: All authors contributed equally to this work. All authors wrote, reviewed and commented on the manuscript. All authors have read and approved the final manuscript.

Conflicts of Interest: The authors declare no conflict of interest. 


\section{Appendix A}

\section{Strategic orientation of the hotel}

\section{Analysis Dimension}

C1. My hotel emphasizes efficacious coordination among its different functional areas.

C2. In my hotel, the information systems are fundamental in making decisions.

C3. Before making a key decision, my hotel completely analyzes the situation.

C4. My hotel uses business-planning techniques.

C5. My hotel uses the data provided by management information and control systems.

C6. My hotel uses manpower planning and assesses the performance of its senior managers.

\section{Aggressiveness dimension}

A1. My hotel sacrifices benefits in order to gain market share.

A2. My hotel cuts prices to increase its market share.

A3. To achieve a good market position, my hotel even sacrifices cash flow and profitability.

-My hotel sets prices below those of the competition.

\section{Defensiveness dimension}

D1. My hotel makes significant modifications in its service processes.

D2. My hotel applies cost control systems to monitor its performance.

D3. My hotel uses production management techniques in its services.

D4. My hotel emphasizes service quality through the use of quality circles.

\section{Futurity dimension}

F1. My hotel uses long-term criteria to assign its resources.

F2. My hotel studies the way to achieve future competitive advantage.

F3. My hotel makes forecasts about the key indicators of its activity.

F4. My hotel formally tracks important general market trends.

F5. My hotel analyzes possible actions in response to critical "what-if" situations.

\section{Proactiveness dimension}

P1. My hotel constantly seeks new opportunities related to its present operations.

P2. My hotel is usually one of the first hotels to launch new services.

P3. In general, my hotel is always ahead of its competitors.

-My hotel constantly looks for new business opportunities.

-As its usual strategy, my hotel eliminates products or services in later stages of their life cycle.

\section{Riskiness dimension}

R1. My hotel's operations can generally be considered "low risk".

R2. My hotel approves new products cautiously, without taking too many risks.

R3. My hotel has a tendency to support projects with guaranteed returns.

R4. My hotel chooses "tried-and-true" low-risk operations.

-My hotel seems to make conservative decisions, and not major decisions.

\section{Level of outsourcing}

N1. Many of the staff of this hotel come from external services companies.

N2. Most of the hotel departments depend on external companies.

N3. This hotel outsources a large number of services.

N4. Many of the hotel's employees are outsourced workers.

N5. A high percentage of the staff are outsourced workers. 


\section{Appendix B}

\section{Organizational performance}

\section{Financial performance}

FP1. Profit margins

FP2. Return of assets

FP3. Profitability of hotel

FP4. Occupancy rate

FP5. Extra income per room

\section{Non-Financial performance}

NFP1. Job satisfaction/employee morale

NFP2. Personnel remuneration and reward of employees

NFP3. Level of satisfaction in the relationships with tour operators

NFP4. Level of satisfaction with suppliers' relationship

NFP5. Level of satisfaction of hotel guests

Note: The items that are not numbered were eliminated from the analysis due to having factor loadings below 0.50 .

\section{References}

1. Chatzoglou, P.D.; Sarigiannidis, L. Business outsourcing and organisational performance: The case of the Greek hotel industry. Int. J. Serv. Technol. Manag. 2009, 11, 105-127. [CrossRef]

2. González, R.; Gasco, J.; Llopis, J. What do we know about outsourcing in hotels? Serv. Ind. J. 2011, 31, 1669-1682. [CrossRef]

3. Tardivo, G.; Bresciani, S.; Cugno, M. Sviluppo Economico ed Infrastrutture: Un'analisi Empirica Delle Province Italiane. Sinergie Rivista di Studi e Ricerche 2013, 92, 115-137.

4. Shani, A.; Uriely, N.; Reichel, A.; Ginsburg, L. Emotional labor in the hospitality industry: The influence of contextual factors. Int. J. Contemp. Hosp. Manag. 2014, 37, 150-158. [CrossRef]

5. Rodríguez-Díaz, M.; Espino-Rodríguez, T.F. Developing relational capabilities in hotels. Int. J. Contemp. Hosp. Manag. 2006, 18, 25-40. [CrossRef]

6. Promsivapallop, P.; Jones, P.; Roper, A. Factors influencing hotel outsourcing decisions in Thailand: Modifications to the transaction cost economics approach. J. Hosp. Tour. Res. 2015, 39, 32-56. [CrossRef]

7. Mukherjee, D.; Gaur, A.S.; Datta, A. Creating value through offshore outsourcing: An integrative framework. J. Int. Manag. 2013, 19, 377-389. [CrossRef]

8. Espino-Rodríguez, T.F.; Lai, P.C.; Baum, T. Risks and benefits of outsourcing hotel operations: A comparison between Scotland and Taiwan. Tour. Econ. 2012, 18, 95-120. [CrossRef]

9. Espino-Rodríguez, T.F; Ramírez-Fierro, J.C. Factors determining hotel activity outsourcing. An approach based on competitive advantage. Int. J. Contemp. Hosp. Manag. 2017, 29, 2006-2026. [CrossRef]

10. González, R.; Gasco, J.; Llopis, J. Outsourcing and strategy in Spanish town halls: A field study. Manag. Deccis. 2013, 51, 97-119. [CrossRef]

11. Venkatraman, N. Strategic Orientation of Business Enterprises: The Construct, Dimensionality, and Measurement. Manag. Sci. 1989, 35, 942-962. [CrossRef]

12. Espino-Rodríguez, T.; Padrón-Robaina, V. A resource-based view of outsourcing and its implications for organizational performance in the hotel sector. Tour. Manag. 2005, 26, 707-721. [CrossRef]

13. Bolat, T.; Yilmaz, Ö. The relationship between outsourcing and organizational performance: Is it mythor reality for the hotel sector? Int. J. Contemp. Hosp. Manag. 2009, 21, 7-23. [CrossRef]

14. Lahiri, S. Does outsourcing really improve firm performance? Empirical evidence and research agenda. Int. J. Manag. Rev. 2016, 18, 464-497. [CrossRef]

15. Hosteltur. La externalización en Hoteles, Tendencia al Alza. Hosteltur, 3 de septiembre 2015. 
16. Redondo-Cano, A.; Canet-Giner, M.T. Oursourcing agrochemical services: Economic or strategic logic? Serv. Bus. 2010, 4, 237-252. [CrossRef]

17. Rhodes, J.; Lok, P.; Loh, W.; Cheng, V. Critical success factors in relationship management for services outsourcing. Serv. Bus. 2016, 10, 59-86. [CrossRef]

18. Quinn, J.; Hilmer, F. Strategic outsourcing. Sloan Manag. Rev. 1994, 35, 43-55.

19. Holcomb, T.R.; Hitt, M.A. Toward a model of strategic outsourcing. J. Oper. Manag. 2007, $25,464-481$. [CrossRef]

20. Espino-Rodriguez, T.; Chun-Lai, P. Activity outsourcing and competitive strategy in the hotel industry. The moderator role of asset specificity. Int. J. Hosp. Manag. 2014, 42, 9-19. [CrossRef]

21. Rumelt, R.P. The evaluation of business strategy. Business Policy and Strategic Management; Glueck, W.F., Ed.; McGraw-Hil: New York, NY, USA, 1980.

22. Hofer, C.W.; Schendel, D. Strategy Formulation: Analytical Concepts; West Publishing Co.: Eagan, MN, USA, 1978.

23. Hofer, C.W.; Murray, E.A.; Charan, R.; Pitts, R.A. Strategic Management. A Casebook in Policy in Planning; West Publishing Co.: Eagan, MN, USA, 1984.

24. Mohiuddin, M.; Su, Z. Offshore outsourcing of core and non-core activities and integrated firm-level performance: An empirical analysis of Québec manufacturing SMEs. Management 2013, 16, 454-478. [CrossRef]

25. McIvor, R. How the transaction cost and resource-based theories of the firm inform outsourcing evaluation. J. Oper. Manag. 2009, 27, 45-63. [CrossRef]

26. Spithoven, A.; Teirlinck, P. Internal capabilities, network resources and appropriation mechanisms as determinants of R\&D outsourcing. Res. Policy. 2015, 44, 711-725.

27. Greaver, M.F., II. Strategic Outsourcing. In A Structured Approach to Outsourcing Decisions and Initiatives; Amacon: New York, NY, USA, 1999.

28. Helfat, C.E.; Peteraf, M.A. The dynamic resource-based view: Capability lifecycles. Strateg. Manag. J. 2003, 24, 997-1010. [CrossRef]

29. Espino-Rodríguez, T.F.; Padrón-Robaina, V. A review of outsourcing from the resource-based view of the firm. Int. J. Manag. Rev. 2006, 8, 49-70. [CrossRef]

30. Avci, U.; Madanoglu, M.; Okumus, F. Strategic orientation and performance of tourism firms: Evidence from a developing country. Tour. Manag. 2010, 31, 1-11. [CrossRef]

31. Han, H. The Relationship among Corporate Culture, Strategic Orientation, and Financial Performance. Cornell Hosp. Q. 2012, 53, 207-219. [CrossRef]

32. Zhou, K.; Li, C. How does strategic orientation matter in Chinese firms? Asia Pac. J. Manag. 2007, 24, 447-466. [CrossRef]

33. Day, G.S. The capabilities of market-driven organizations. J. Mark. 1994, 58, 37-52. [CrossRef]

34. Gatignon, H.; Xuereb, J.M. Strategic Orientation of the Firm and New Product Performance. J. Mark. Res. 1997, 34, 77-90. [CrossRef]

35. Ginsberg, A.; Venkatraman, N. Contingency perspectives of organizational strategy: A critical review of empirical research. Acad. Manag. Rev. 1985, 10, 21-34. [CrossRef]

36. Abiodun, A.J. Exploring the Relationship between Human Personal Values, Strategy Dimensions and Performance. Ann. Univ. Buchar. Econ. Adm. Ser. 2009, 3, 237-244.

37. Porter, M. Competitive Strategy; Free Press: New York, NY, USA, 1980.

38. Chang, S.C.; Lin, N.P.; Wea, C.L.; Sheu, C. Aligning manufacturing strategy with business strategy: An empirical study in high-tech industry. Int. J. Technol. Manag. 2002, 24, 70-87. [CrossRef]

39. Hitt, M.; Hoskisson, R.; Ireland, D. Management of Strategy: Concepts and Cases; Thomson/South Western Publishers: Mason, OH, USA, 2006.

40. Wissema, J.; Van der Pol, H.; Messer, M. Strategic management archetypes. Strateg. Manag. J. 1980, 1, 37-47. [CrossRef]

41. Schuler, R.; Jackson, S. Linking competitive strategy with human resource management practices. Acad. Manag. Exec. 1987, 1, 207-219. [CrossRef]

42. Mintzberg, H. Generic strategy: Toward a comprehensive framework. Adv. Strateg. Manag. 1988, 5, 1-67.

43. Miles, R.; Snow, C. Organisational Strategy, Structure and Process; McGraw-Hill: New York, NY, USA, 1978.

44. Thompson, J. Organizations in Action; MacGraw-Hill: New York, NY, USA, 1967.

45. Miles, R.; Cameron, K. Coffin Nails and Corporate Strategies; Prentice-Hall: Englewood Cliffs, NJ, USA, 1982. 
46. Stambaugh, J.; Yu, A.; Dubinsky, A. Before the Attack: A Typology of Strategies for Competitive Aggressiveness. J. Manag. Policy Pract. 2011, 12, 49-63.

47. Ayodotun, I.; Hezakiah, F. Impact of Strategic Orientation Dimensions on New Product Development in Agro-based Nigerian Firms. Econ. Manag. Res. Proj. Int. J. 2015, 3, 1-8.

48. Mariotti, S.; Cainarca, G. The Evolution of Transaction Governance in the Textile-Clothing Industry. J. Econ. Behav. Organ. 1986, 7, 351-374. [CrossRef]

49. Jiang, B.; Frazier, G.V.; Prater, E.L. Outsourcing effects on firms' operational performance: An empirical study. Int. J. Oper. Prod. Manag. 2006, 26, 1280-1300. [CrossRef]

50. Bengtsson, L.; Dabholkar, M. Manufacturing outsourcing and its effect on plant performance-lessons for KIBS outsourcing. J. Evolut. Econ. 2009, 19, 231-257. [CrossRef]

51. Kroes, J.; Ghosh, S. Outsourcing congruence with competitive priorities: Impact on supply chain and firm performance. J. Oper. Manag. 2010, 28, 124-143. [CrossRef]

52. Elmuti, D. The perceived impact of outsourcing on organizational performance. Am. J. Bus. 2003, 18, 33-42. [CrossRef]

53. Lee, C.C.; Lin, T.T.; Cheng, P.C. The determinants of the transportation outsourcing strategy for the express delivery company. Serv. Bus. 2013, 7, 207-225. [CrossRef]

54. Sukru Cetinkaya, A.; Ergul, M.; Uysal, M. Quality of relationship on information technology outsourcing for organizational success in hospitality industry. J. Hosp. Tour. Technol. 2014, 5, 229-244. [CrossRef]

55. Mantel, S.P.; Tatikonda, M.V.; Liao, Y. A behavioral study of supply manager decision-making: Factors influencing make versus buy evaluation. J. Oper. Manag. 2006, 24, 822-838. [CrossRef]

56. Espino-Rodríguez, T.F.; Chun-Lai, P.; Gil-Padilla, A.M. Does outsourcing moderate the effects of asset specificity on performance? An application in Taiwanese hotels. J. Hosp. Tour. Manag. 2017, 31, 13-27. [CrossRef]

57. Gilley, K.M.; Greer, C.R.; Rasheed, A.A. Human resource outsourcing and organizational performance in manufacturing firms. J. Bus. Res. 2004, 57, 232-240. [CrossRef]

58. Salimath, M.S.; Cullen, J.B.; Umesh, U.N. Outsourcing and Performance in Entrepreneurial Firms: Contingent Relationships with Entrepreneurial Configurations. Decis. Sci. 2008, 39, 359-381. [CrossRef]

59. Thouin, M.F.; Hoffman, J.J.; Ford, E.W. IT outsourcing and firm-level performance: A transaction cost perspective. Inf. Manag. 2009, 46, 463-469. [CrossRef]

60. Kamyabi, Y.; Devi, S. Accounting outsourcing and firm performance in Iranian SMEs. Int. J. Econ. Financ. 2011, 3, 181. [CrossRef]

61. Instituto Nacional de Estadística. Encuesta de Ocupación Hotelera. Available online: http://www.ine.es (accessed on 8 March 2018).

62. Encuesta de Alojamiento Turístico (ISTAC). Tourism Board Gran Canaria: Situación Sector Turístico; Gobierno de Canarias: Gran Canaria, Spain, 2018.

63. Hult, G.T.; Ketchen, D.J.; Arrfelt, M. Strategic supply chain management: Improving performance through a culture of competitiveness and knowledge development. Strateg. Manag. J. 2007, 28, 1035-1052. [CrossRef]

64. Venkatraman, N.; Ramanujam, V. Measurement of business performance in strategy research: A comparison of approaches. Acad. Manag. Rev. 1986, 11, 801-814. [CrossRef]

65. Garrigós-Simón, F.J.; Palacios Marqués, D.; Narangajavana, Y. Competitive strategies and performance in Spanish hospitality firms. Int. J. Contemp. Hosp. Manag. 2005, 17, 22-38. [CrossRef]

66. Sin, L.Y.; Alan, C.B.; Heung, V.C.; Yim, F.H. An analysis of the relationship between market orientation and business performance in the hotel industry. Int. J. Hosp. Manag. 2005, 24, 555-577. [CrossRef]

67. Espino-Rodríguez, T.F.; Gil-Padilla, A.M. The structural and infrastructural decisions of operations management in the hotel sector and their impact on organizational performance. Tour. Hosp. Res. 2015, 15, 3-18. [CrossRef]

68. Tavitiyaman, P.; Qu, H.; Zhang, H.Q. The impact of industry force factors on resource competitive strategies and hotel performance. Int. J. Hosp. Manag. 2011, 30, 648-657. [CrossRef]

69. Podsakoff, P.M.; MacKenzie, S.B.; Lee, J.-Y.; Podsakoff, N.P. Common method biases in behavioral research: A critical review of the literature and recommended remedies. J. Appl. Psychol. 2003, 88, 88-879. [CrossRef] [PubMed]

70. Arend, R.J. Ethics-focused dynamic capabilities: A small business perspective. Small Bus. Econ. 2013, 41, 1-24. [CrossRef] 
71. Wohlgemuth, V.; Wenzel, M. Dynamic capabilities and routinization. J. Bus. Res. 2016, 69, $1944-1948$. [CrossRef]

72. Ringle, C.; Wende, S.; Will, A. SmartPLS 2.0 (M3) $\beta$; Springer: Hamburg, Germany, 2005.

73. Hair, J.F., Jr.; Hult, G.T.M.; Ringle, C.; Sarstedt, M. A Primer on Partial Least Squares Structural Equation Modeling (PLS-SEM); Sage Publications: Thousand Oaks, CA, USA, 2016.

74. Chin, W.; Marcolin, B.; Newsted, P. A partial least squares latent variable modeling approach for measuring interaction effects: Results from a monte carlo simulation study and an electronic-mail emotion/adoption study. Inf. Syst. Res. 2003, 14, 189-217. [CrossRef]

75. Falk, R.; Miller, N. A Primer for Soft Modeling; The University of Akron Press: Akron, OH, USA, 1992.

76. Barclay, D.; Higgins, C.; Thompson, R. The partial least squares (PLS) approach to casual modeling: Personal computer adoption and use as illustration. Technol. Stud. 1995, 2, 285-309.

77. Chin, W. The partial least squares approach for structural equation modeling. In Modern Methods for Business Research; Marcoulides, G.A., Ed.; Lawrence Erlbaum Associates: London, UK, 1998; pp. 236-295.

78. Hasan, B.; Ali, J. An empirical examination of factors affecting group effectiveness in information systems projects. Decis. Sci. J. Innov. Educ. 2007, 5, 229-243. [CrossRef]

79. Nunnally, J. Psychometric Theory, 2nd ed.; McGraw-Hill: New York, NY, USA, 1978.

80. Diamantopoulos, A.; Siguaw, J.A. Formative versus reflective indicators in organizational measure development: A comparison and empirical illustration. Br. J. Manag. 2006, 17, 263-282. [CrossRef]

81. Tenenhaus, M.; Vinci, V.E.; Chatelin, Y.; Lauro, C. PLS Path Modeling. Comput. Stat. Data Anal. 2005, 48, 159-205. [CrossRef]

82. Zhao, X.; Huo, B.; Selen, W.; Yeung, J.H.Y. The impact of internal integration and relationship commitment on external integration. J. Oper. Manag. 2011, 29, 17-32. [CrossRef]

83. Espino-Rodríguez, T.F.; Ramírez-Fierro, J.C. Managers' attitudes toward hotel outsourcing in a tourist destination. An approach from the benefits and risks perspective. Tour. Manag. Perspect. 2018, 26, 143-152. [CrossRef]

84. Mudambi, R.; Venzin, M. The strategic nexus of offshoring and outsourcing decisions. J. Manag. Stud. 2010, 47, 1510-1533. [CrossRef] 